\title{
Assessment of the nutritive value of toasted castor seed cake-based diets as a reflect on blood profile of weanling wistar albino rats
}

\author{
Agboola, A. F
}

Department of Animal Science, University of Ibadan, Ibadan, Nigeria

\begin{abstract}
Corresponding author: adebisi.agboola@gmail.com, +234(8)022004830
\end{abstract}
Since the cost of feed is increasing due to the keen competition between humans and animals, there is a need to critically seek for a matching alternative. Castor seed cake, a residue after the extraction of oil from nutrients-rich castor seed constitutes a waste which can be converted into livestock feed. Thus, the study was carried out to investigate the effect of graded levels of castor seed cake diets on haematological and serum biochemical indices of weanling albino rats in an experiment that lasted 21 days. Thirty weanling Wistar albino rats were weighed individually and randomly assigned to 5 dietary treatments with 3 replicates of two rats in a completely randomized design. Diet 1 was a nitrogen-free diet (NFD), while diets 2, 3, 4, and 5 had $0 \%$ (without castor seed cake inclusion), 2, 4 and 6\% castor seed cake replacing soyabean meal respectively. At day 21, blood samples were obtained from two rats per replicate for haematological and serum analysis. There were no significant differences $(P>0.05)$ observed in all the parameters (packed cell volume, haemaglobin, red blood cell, white blood cell, lymphocyte, neutrophil, monocyte, eosinophil and platelet) measured. Similarly, diet had no effect on the serum biochemical indices (creatinine, urea, total protein and globulin) measured. Significant difference $(P<0.05)$ was however observed in albumin $(2.62-3.18 \mathrm{~g} / \mathrm{dL})$ of rats on the different experimental diets. The albumin concentrations of weanling albino rats on dietary treatments were similar to those on the control diet but significantly $(P<0.05)$ higher $(3.09-3.18 \mathrm{~g} / \mathrm{dL})$ than those on the nitrogen-free diet. It can be concluded that castor seed cake can replace soyabean meal up to $6 \%$ inclusion level without eliciting detrimental effect on blood profile of weanling wistar albino rats.

Keywords: Castor seed cake, Albino rat, Haematological parameters, Serum biochemical indices

\section{Introduction}

Castor bean (Ricinus communis L.) is an oilseed shrub of significant economic importance because of its several potentials in industry and medicine. The plant, is a species of flowering plant in the spurge family, Euphorbiaceaes and the sole species in the monotypic genus, Ricinus, and sub-tribe, Ricininae. Castor is indigenous to the south eastern Mediterranean basin, Eastern African and India, but it is widespread throughout tropical regions (and widely grown elsewhere as an ornamental plant). It is abundant along water courses and flood plains, disturbed or waste land (Lima Da Silva et al., 2006; Berman et al., 2011;
Akande et al., 2014). Castor seeds contain between $40 \%$ and $60 \%$ oil that is rich in triglycerides, mainly ricinolein, $38.58 \%$ crude protein (Akande et al., 2012), is a good source of phosphorous, sodium, potassium, magnesium (Agbabiaka et al., 2011) and calcium (Annongu and Joseph, 2008) necessary in both human and livestock diets but low in iron, copper and manganese. Threonine and methionine are the first limiting amino acids in castor seed meal (Puttaraj et al., 1994) and other indispensable amino acids are isoleucine and lysine (Annongu and Joseph, 2008) compared to the standard plant protein source soyabean. However, utilization of castor bean cake in livestock feed is limited 


\section{Blood metabolites of weanling albino rats fed castor seed cake diets}

due to the presence of antinutritional factors such as: ricin, ricinine and thermostable allergen (Darby et al., 2001; Olsnes, 2004) which are present in the seed and in lower concentrations throughout the plant. Various processing methods like genetic manipulation, chemical (lye, ammonia salt, blanching, sodium hydroxide treatment), physical (germination, sprouting, fermentation), heat (boiling, steaming, autoclaving, microwave cooking) and mechanical methods (crushing, decortications, dehulling) (El- Adawy, 2002; Anandan et al., 2005; Emiola et al., 2007; Soetan, 2008; Ani and Okorie, 2009; Akande et al., 2011; 2012; 2014) have been employed to detoxify the anti-nutritive factors in castor oil bean but with distinct inherent limitations. According to Akande et al. (2012), lye-treated castor bean cake had low calcium content. Germinated castor seed had low crude protein which was traced to nitrogen used up during germination (Akande et al., 2014). Cooking treatments and/or germination caused decreased fat, total ash, carbohydrate fractions, minerals, Bvitamins and the concentrations of lysine, tryptophan, total aromatic and sulfurcontaining amino acids (Soetan and Oyewole, 2009). However, castor bean has been suggested for use in livestock feed as an alternative protein source if properly detoxified.

The blood contains myriad of metabolites and other constituents, which provide a valuable medium for clinical investigation and nutritional status of animals. According to Church (1991), dietary components have measurable effects on blood constituents such that significant changes in their values could be used to draw inference on the nutritive value of feeds offered to the animals. It was therefore the aim of this study to determine the effect of castor seed cake diets on the haematological and serum biochemical indices of weanling wistar albino rats.

\section{Materials and methods Experiment site}

The experiment was carried out at the rats house (rat metabolic cages), Department of Animal Science, University of Ibadan, Ibadan, Nigeria.

Preparation of test ingredient, experimental diets and management of animals

The castor oil bean used was harvested along watercourses and floodplains, disturbed on waste land in Ibadan Metropolis, Akinyele Local Government Area, Oyo state. The castor seeds were toasted, by spreading out the seeds in an even layer, heated over medium heat and shaken often until the seeds were golden brown and removed from pan to cool for about 20 minutes. The oil was then extracted with the use of mechanical screw press. The resultant cake from oil extracted processed castor seeds was autoclaved at $120^{\circ} \mathrm{C}$ for $15 \mathrm{~min}$.

Thirty weanling wistar albino rats were purchased from a reputable rat farm in Ibadan, Nigeria. The metabolic rats' house was cleaned and disinfected prior to arrival day. The animals were randomly allotted to five treatments comprising three replicates of paired rats per replicate. Each group received one of the experimental diets (Table 1) and was fed for 21 days. Diet 1 was a nitrogen-free diet, diet 2 was the basal diet without castor seed cake. Diets 3 was the basal diet with $2 \%$ castor seed cake inclusion while diets 4 and 5 contained the basal diet with inclusion of 4 and $6 \%$ castor seed cake respectively in a completely randomized design. The rats were fed ad libitum and had access to clean water. 


\section{Agboola}

\section{Blood collection}

Blood samples were obtained through ocular puncture from two rats per replicate at day 21 of the experiment into a bottle containing EDTA (ethylene diamine tetra acetic acid) for haematological studies while another set of bottles were without EDTA for subsequent serum separation.

Haematological parameters of albino rats fed toasted castor seed cake diets

The packed cell volume (PCV) and haemoglobin $(\mathrm{Hb})$ were determined using the micro haematocrit method and cyanmethehaemoglobin method respectively as described by Mitruka and Rawnsley (1981). Erythrocyte count (RBC) and Leukocyte count (WBC) were determined using the improved Neubauer haemocytometer after the appropriate dilution (Schalm et al., 1975). Differential leukocyte counts were determined by scanning Giemsa's stained slides in the classic manner (Schalm et al., 1975).

Table 1: Gross composition (g\100g DM) of experimental diets fed to rats

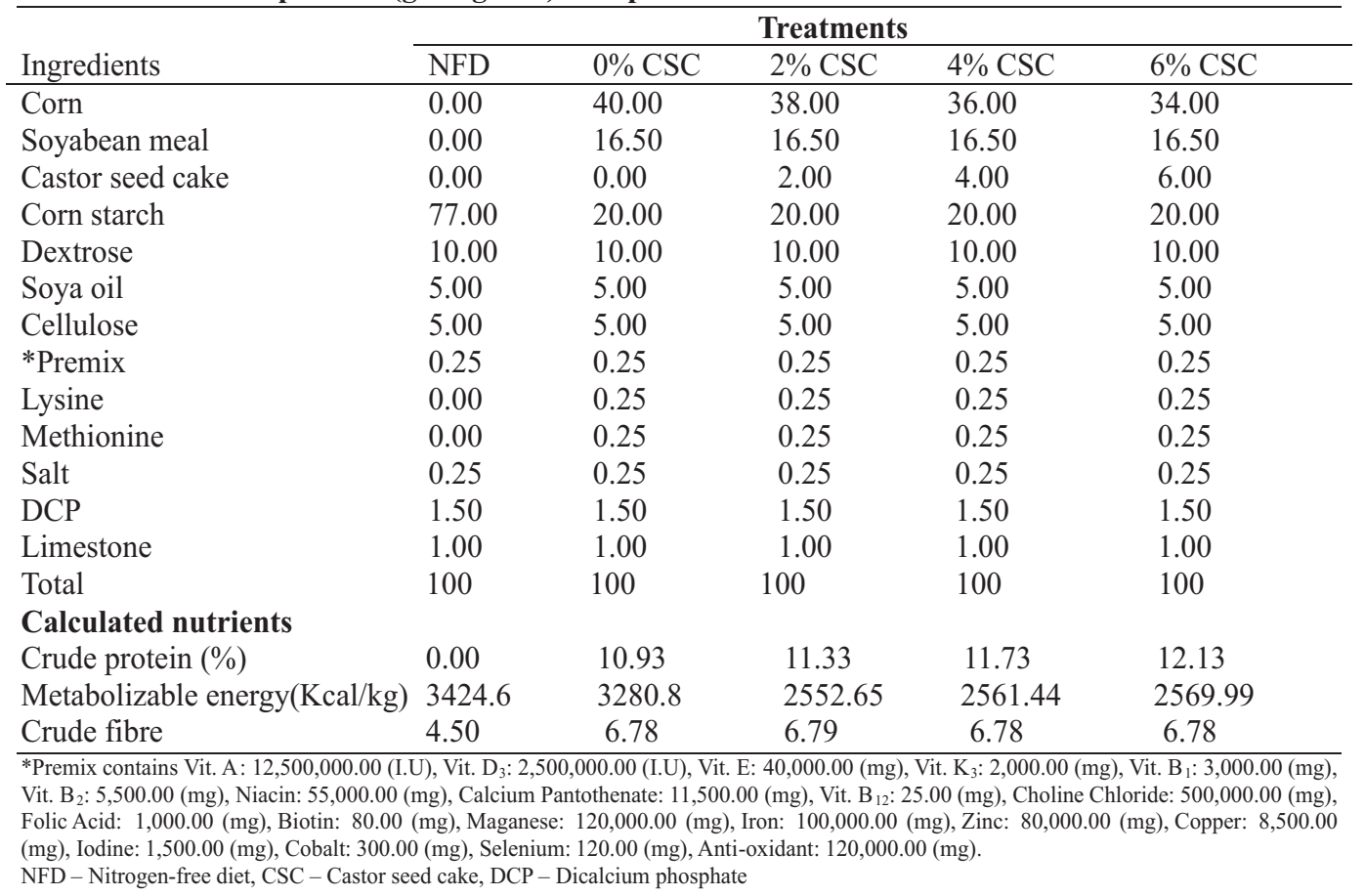

Serum biochemical indices of albino rats fed toasted castor seed cake diets

Glucose, cholesterol and triglyceride were assayed by the methods of Roschlan et al. (1974). Serum urea was determined by the kit (Quinica Clinica Spam), a uricase method as described by Wootton (1964). The biuret method was utilized in the determination of the total protein fraction while the serum was subjected to the direct colorimetric method for albumin with bromocresol green (BCG) as the dye as described by Peters et al. (1982).

\section{Statistical analysis}

Data were subjected to a one-way analysis of variance using SAS (2008) software and the mean separated by Tukey's HSD option of the same software package. 


\section{Blood metabolites of weanling albino rats fed castor seed cake diets}

\section{Results}

Haemtological indices of albino rats fed toasted castor seed cake diets

Results of the haematological indices of albino rats fed toasted castor seed diets are shown in Table 2. There were no significant differences $(\mathrm{P}>0.05)$ observed in all the parameters (packed cell volume, haemaglobin, red blood cell, white blood cell, lymphocyte, neutrophil, monocyte, eosinophil and platelet) measured.

Table 2: Haematological parameters of albino rat fed with diffe rent levels of toasted castor seed cake diets

\begin{tabular}{|c|c|c|c|c|c|c|c|}
\hline \multirow[b]{2}{*}{ Parameters } & \multicolumn{4}{|c|}{ Treatments } & \multirow[b]{2}{*}{$6 \% \mathrm{CSC}$} & \multirow[b]{2}{*}{ SEM } & \multirow[b]{2}{*}{ P value } \\
\hline & NFD & Control & $2 \% \mathrm{CSC}$ & $4 \% \mathrm{CSC}$ & & & \\
\hline PCV (\%) & 43.00 & 39.67 & 42.00 & 39.33 & 40.33 & 1.21 & 0.2283 \\
\hline $\mathrm{Hb}(\mathrm{g} / \mathrm{dL})$ & 14.37 & 13.50 & 13.90 & 13.07 & 13.47 & 0.38 & 0.2355 \\
\hline $\mathrm{RBC}\left(\mathrm{x} 10^{12 / \mathrm{L}}\right)$ & 7.34 & 6.70 & 7.08 & 6.61 & 6.65 & 0.23 & 0.1678 \\
\hline $\mathrm{WBC}\left(\times 10^{9 / \mathrm{L}}\right)$ & 6.03 & 7.52 & 10.07 & 5.25 & 7.82 & 1.04 & 0.0617 \\
\hline Lymphocyte $\left(\mathrm{x} 10^{3 / \mathrm{mm} 3}\right)$ & 66.00 & 68.33 & 56.00 & 66.33 & 66.67 & 3.58 & 0.1876 \\
\hline Neutrophil $\left(\mathrm{x} 10^{3 / \mathrm{mm} 3}\right)$ & 31.00 & 27.00 & 38.67 & 29.67 & 29.00 & 3.32 & 0.2011 \\
\hline Monocyte $\left(\mathrm{x} 10^{3 / \mathrm{mm} 3}\right)$ & 1.67 & 2.00 & 2.33 & 2.33 & 1.67 & 0.54 & 0.8149 \\
\hline Eosinophil (x10 $\left.10^{3 / \mathrm{mm}^{3}}\right)$ & 1.33 & 2.67 & 3.00 & 1.67 & 2.67 & 0.65 & 0.3558 \\
\hline Platelet $\left(\mathrm{x} 10^{3 / \mathrm{mm} 3}\right)$ & 134.67 & 154.00 & 180.67 & 157.67 & 158.00 & 19.45 & 0.6056 \\
\hline
\end{tabular}

Mean along the same row with the same superscripts are not significantly $(\mathrm{P}>0.05)$ different

NFD - Nitrogen-free diet; Hb - Haemaglobin, RBC - Red blood c ell; WBC - White blood cell, PCV - Packed cell volume, CSC - Castor seed cake, SEM- Standard error mean

Serum biochemical indices of albino rats fed toasted castor seed cake diets

The serum biochemical indices of rats fed different levels of toasted castor seed cake are shown in Table 3. Diet had no effects on serum biochemical indices (creatinine, urea, total protein and globulin) measured.
However, there was significant difference $(\mathrm{P}<0.05)$ observed in serum albumin concentration of rats on experimental diets. The albumin of weanling albino rats on dietary treatments were similar to those fed the control diet but significantly $(\mathrm{P}<0.05)$ higher than those fed nitrogen-free diet.

Table 3 : Serum biochemical indices of albino rats fed on different levels of toasted castor seed cake diets

\begin{tabular}{|c|c|c|c|c|c|c|c|}
\hline \multirow[b]{2}{*}{ Parameters } & \multicolumn{5}{|c|}{ Treatments } & \multirow[b]{2}{*}{ SEM } & \multirow[b]{2}{*}{$\mathrm{P}$ value } \\
\hline & NFD & Control & $2 \% \mathrm{CSC}$ & $4 \% \mathrm{CSC}$ & $6 \% \mathrm{CSC}$ & & \\
\hline Creatinine(mg/dL) & 1.02 & 1.07 & 0.92 & 0.97 & 1.01 & 0.08 & 0.6949 \\
\hline Urea $(\mathrm{mg} / \mathrm{dL})$ & 13.75 & 23.09 & 20.44 & 20.69 & 18.75 & 3.26 & 0.3903 \\
\hline Total Protein $(\mathrm{g} / \mathrm{dL})$ & 5.46 & 6.12 & 5.42 & 5.74 & 5.36 & 0.37 & 0.6051 \\
\hline Albumin (g/dL) & $2.62^{\mathrm{b}}$ & $3.11^{\mathrm{a}}$ & $3.14^{\mathrm{a}}$ & $3.09^{\mathrm{a}}$ & $3.18^{\mathrm{a}}$ & 0.09 & 0.0139 \\
\hline Globulin (g/dL) & 2.84 & 3.01 & 2.28 & 2.65 & 2.18 & 0.42 & 0.6005 \\
\hline
\end{tabular}

${ }^{\text {ab }}$ Mean along the same row with different superscripts are significantly $(\mathrm{P}<0.05)$ different

NFD - Nitrogen free diet, SEM- Standard error mean, CSC - Castor seed cake

\section{Discussion}

\section{Haematological indices of albino rats fed} toasted castor seed cake diets

The act of interpreting blood profile in normal and diseased condition of animal is part of the primary objectives of haematologic studies (Khan and Zafar,
2005). The results on haematological parameters of albino rats indicated that dietary inclusion had no significant effect on the blood parameters measured. This is in agreement with the study carried out by Oso et al. (2004) who assessed effect of feeding graded levels (50, 100 and $150 \mathrm{gkg}^{-1}$ ) of 


\section{Agboola}

fermented castor oil seed meal to Nera strain chicks. The authors reported no significant effect on packed cell volume (PCV), haemoglobin ( $\mathrm{Hb})$, red blood cell (RBC), neutrophil, and eosinophil. Adedeji et al. (2006) reported similar findings in rabbits fed $0,10,15,20$ and $25 \%$ inclusion levels of boiled castor seed cake. The authors asserted that diets had no effect on $\mathrm{Hb}, \mathrm{PCV}, \mathrm{RBC}$, white blood cell (WBC), neutrophils, eosinophils and lympocytes of the rabbits. Also, Colette et al. (2013) observed that inclusion of dried rumen content and castor oil seed cake to diets of broilers had no significant effect on RBC and WBC, although PCV was affected. In a study conducted by Apata et al. (1999), 50 and $100 \mathrm{~g} / \mathrm{kg}$ detoxified castor seed cake in weaner pigs' diets had no effect on haematological parameters and serum biochemical indices measured. The authors averred that the similarity in the various blood constituents in pigs on treatments further substantiated the nutritional adequacy and safety of detoxified CSC diets up to inclusion level of $100 \mathrm{~g} / \mathrm{kg}$.

However, a contrary opinion was asserted in the findings by Akande and Odunsi (2012). The authors observed that PCV, Hb and WBC values were influenced by moist heated and fermented or lye treated diets fed to150 day-old Anak broiler chicks. Momoh et al. (2012) recorded reduced PCV and increased WBC values in albino rats fed castor seed oil extract. Shindang et al. (2012) also reported a decrease in PCV and increase in WBC when dried ground Ricinus communis var minor seeds were fed to female albino rabbits.

Serum biochemical indices of albino rat fed with toasted castor seed cake diets

Blood parameters could be used to indicate the physiologic, pathologic and nutrition status of an animals (Colette et al., 2013). The detection of organ disease in animal and availability of protein in the diets are revealed in the serum (Iyayi and Tewe, 1998). Adeyemi et al. (2000) reported that the quality of diet is positively correlated to serum biochemistry. Serum biochemical indices measured were remarkably similar except albumin. Deldar (1994) reported that albumin is the most common protein in blood plasma. Albumin of rats on nitrogenfree diet was significantly lower than those on other diets. This is probably an indication of the absence of protein in their diet. Serum creatinine levels indicate the extent of muscle degradation in animals. When the values are high, it shows a high degradation of muscle phospho-creatinine to form creatinine (MacWilliams et al., 1982). Creatinine values recorded in this study had no difference and were higher than the normal reference range while the results of blood urea nitrogen observed were within the normal range according to Mitruka and Rawnsley (1981). The higher level of creatinine in this study is an indication of muscle wastage in the albino rats due to the treatment imposed. The serum urea test measures the amount of nitrogen in the serum. High serum urea level is probably an indication of kidney dysfunction, because protein intake and kidney functioning are affected by quantity of blood urea nitrogen. Diet had no influence on the blood urea of the experimental rats. The values obtained were within the normal reference range of albino rat (Mitruka and Rawnsley, 1981) implying that the kidney was unaffected and there was a better utilization of protein since blood urea can be attributed to protein breakdown. A contrary view was observed in the findings of Akande et al. (2013) who reported influence of treated castor bean cake on urea and creatinine levels in Anak broiler chicks. However, Oso et al. (2004) findings agreed with the result of the present study except for serum albumin which was 


\section{Blood metabolites of weanling albino rats fed castor seed cake diets}

not affected fermented castor oil seed meal up to $150 \mathrm{~g} / \mathrm{Kg}$ in diets of Nera broiler chicks while Adedeji et al. (2006) had similar findings on serum biochemical indices when weaner rabbits were fed graded levels $(0,10,15,20$ and $25 \%)$ of boiled castor seed cake.

\section{Conclusion}

Results from this study showed that castor seed cake can replace soyabean meal up to $6 \%$ inclusion level without eliciting any deleterious effect on blood profile of weanling wistar albino rats.

\section{References}

Adedeji, J. A., Apata, D. F., Aderinola, O. A., Rafiu, T. A. and Amao, S. R. 2006 . Performance and h a e matolog i c l/s e r u m characteristics of rabbits fed boiled castor seed cake-based diet. World Journal of Zoology 1 (2): 91-93.

Adeyemi, O. A., Fashina, O. E. and Balogun, M. O. 2000. Utilization of full-fat Jastropha seed in broiler diet: Effect on haematological parameters and blood chemistry. In: Processing. $25^{\text {th }}$ Annual Conference Nigeria Society Animal Production. (NSAP) $19^{\text {th }}-23^{\text {rd }}$ March, 2000, Umudike. Page. 108-109.

Agbabiaka, L. A., Esonu, B. O. and Madubuike, F. N. 2011. Effect of processing on nutrients and antinutrients of castor oil bean (Ricinus communis) seeds and by-products. Pakistan Journal of Nutrition 10 (6): 561-563

Akande, T. O. and Odunsi, A. A. 2012. Nutritive value and biochemical changes in broiler chickens fed detoxified castor kernel cake based diets. African Journal of Biotechnology 11(12): 2904-2911.
Akande, T. O., Odunsi, A. A. and Adedeji, O. S. 2011. Toxicity and Nutritive Assessment of Castor (Ricinus communis) Oil and Processed Cake in Rat Diet. Asian Journal of Animal Sciences. 5:330339.

Akande, T. O., Odunsi, A. A., Olabode, O. S. and Ojediran, T. K. 2012. Physical and nutrient characterisation of raw and processed castor (Ricinus communis L.) seeds in Nigeria. World Journal of Agricultural Sciences. 8(1): 89-95.

Akande, T. O., Odunsi, A.A., Rafiu, T.A., Olaniyi, C. O. and Binuomote, R. T. 2013. Growth and serological assessment of broiler chickens fed differently processed castor (Ricinus communis Linn.) kernel cake based diets. African Journal of Agricultural research. 8 (41): 5161-5165.

Akande T. O., Odunsi A. A., Emiola A. O. and Adedeji O. S. 2014. Evaluation of growth performance and hepatic histological changes in albino rats fed varying levels of differently treated castor bean cake based diets. Journal of Animal Science Advances. 4(1): 641-647.

Anandan, S., Kumar, G. K. A., Ghosh, J. and Ramachandra, K. S. 2005. Effect of different physical and chemical treatments on detoxification of ricin in castor cake. Animal Feed Science Technology. 120: 159-168.

Ani, A. O. and Okorie, A. U. 2009. Response of broiler finishers to diets containing graded levels of processed castor oil bean (Ricinus communis L) meal. J Anim Physiol Anim Nutr 93(2): 157-164. 
Annongu, A. A. and Joseph, J. K. 2008. Proximate Analysis of Castor Seeds and Cake. Journal Applied Science Environment Management. 12(1)39-41.

Apata, D. F., Bamisile, A. B., Oyebanji, S. S. and Bamgbose, A. M. 1999. Response of young pigs to dietary levels of detoxified castor seed cake. Book of Proceedings: $26^{\text {th }}$ Annual NSAP conference, Ilorin, 275-277.

Berman, P., Nizri, S. and Wiseman, $Z$. 2011. Castor oil biodiesel and its blends as alternative fuel. Biomass Bioenergy. 35: 2861-2866.

Church, D. C. 1991. Livestock feed and feeding: 3rd ed. Regents, Prentice Hall, Englewood Cliffs, New Jersey.

Colette, N. T. N., Fotsa, J. C., Etchu, K. A. and Ndamukong K. J. N. 2013. Effects of dried rumen content and castor oil seed cake diets on haematological indices, serum biochemistry and organoleptic properties of broiler birds. Sky Journal of Agricultural Research. 2(9): $120-125$.

Darby, S. M., Miller, M. L. and Allen, R. O. 2001. Forensic determination of ricin and alkaloid marker ricinine from castor bean extract. Journal of Forensic Science. 46: 1033-1042.

Deldar, A. 1994. Blood and bone marrow. In: veterinary history. $5^{\text {th }}$ ed. Williams and Wilkins. A waverly company. 4: 62-71.

El-Adawy, T. A. 2002. Nutritional composition and anti-nutritional factors of chickpeas (Cicer arietinum $L$.) undergoing different cooking methods and germination. Plant Foods for Human Nutrition (formerly Qualitas Plantarum). 57(1): 83-87.

Emiola, I. A., Ologboho, A. D. and Gous, R. M. 2007. Performance and histological responses of internal organs of broiler chickens fed raw, dehulled, aqueous and dry- heated kidney bean meal. Poultry Science Journal. 86: 1234-1240.

Iyayi, E. A. and Tewe, O. O. 1998. Serum total protein, urea and creatinine levels as indices of quality of cassava diets for pigs. Tropical Veterinary, 16: 59-67.

Khan, T. A. and Zafar, F. 2005. Haematological study in response to varying doses of estrogen in broiler chicken. International Journal of Poultry Science, 4 (10): 748-751.

Lima Da Silva, N., Maciel, M .R. W., Batistella, C. B. and Filho, R. M. 2006. Optimization of biodiesel production from castor oil. Applied Biochemistry and Biotechnology. 130: 405-414.

MacWilliams, P. S., Searcy, G. P. and Bellamy, J. C. E. 1982. Bovine post-parturient haemoglobinuria. Canadian Veterinary Journal, 23: $309-312$.

Mitruka, B. M. and Rawsley, H. M. 1981. Clinical Biochemical and Haematological reference values in normal experimental animals and normal human. $2^{\text {nd }}$ ed. Masson publishing New York. 413.

Momoh A. O., Oladunmoye M. K. and A d e b o l u T. T. 2012 . $\mathrm{H}$ a e m a to 1 og i c a 1 a d histopathological effects of oil from castor seeds (Ricinus communis Linn) on albino-rats. Journal of Pharmacognosy and Phytotherapy. 4(4): 40-43. 


\section{Blood metabolites of weanling albino rats fed castor seed cake diets}

Olsnes S. 2004. The history of ricin, abrin and related toxins. Toxin contaminant. 44(4): 361-370.

Oso, A. O. 1., Olayemi, W. A. 1, Bamgbose, A. M. 1 and Fowoyo, O. F. 2004. Utilization of fermented castor oil seed (Ricinus communis, L) meal in diets for cockerel chicks. Archectical Zootechnology. 60(229): 75-82.

Peters, T., Biaamonte, G. T and Doumas, B. T .1982. Protein (total protein) in serum urine and cerebrospinal fluid: albumin in serum. In: Selected method of clinical chemistry. American Association for Clinical Chemistry, Washington, DC.

Puttaraj, S., Bhagya, S., Murthy K. N. and Singh, N. 1994. Effect of detoxification of castor seed (Ricinus communis) protein isolate on its nutritional quality. Plant Foods for Human Nutrition. 46(1): 63-70.

Roschlan, P., Bernet, E. and Gruber, W. 1974. Ezymatische best immungoles gesamt Cholesterius in serum. Journal of Clinical Chemistry and Biochemistry, 12: 403-407.

SAS. 2008. Statistical Analysis System, SAS users guide: statistics. SAS
Institute Inc. cary, N.C. USA.

Schalm, O. W., Jain, N. C. and Carroll, E. J. 1975. Veterinary Haematology. 3rd Edn., Lea and Febiger, Philadelphia, 15-218.

Shindang, C. O., Shindang, J. and Enweani, I. B. 2012. Immunogenic properties of Ricinus Communis Var minor seed on female albino rabbits. Nigerian Journal of Biotechnology. 24: 7-12.

Soetan, K. O. 2008. Pharmacological and other beneficial effects of antinutriional factors in plants. $-\mathrm{A}$ Review. African Journal of Biotechnology. 7(25): 4713-4721.

Soetan, K. O. and Oyewole, O. E. 2009. The need for adequate processing to reduce the antinutritional factors in plants used as human foods and animal feeds: A review. African Journal of Food Science. 3 (9): 223-232.

Wootton, D. P. 1964. Micro-analysis in medical biochemistry, 4th ed., 86 . Churchill, London.

Received: $7^{\text {th }}$ March, 2017 Accepted: 21 ${ }^{\text {st }}$ June, 2017 